\title{
A PALEOECOLOGICAL RECONSTRUCTION OF THE LATE GLACIAL AND HOLOCENE BASED ON MULTIDISCIPLINARY STUDIES AT STEREGOIU SITE (GUTÂI MTS., NW ROMANIA)
}

\author{
ANGELICA FEURDEAN ${ }^{1}$, LEIF BJÖRKMAN ${ }^{2}$, BARBARA WOHLFARTH ${ }^{2}$
}

\begin{abstract}
High resolution analyses of pollen, mineral magnetic properties, loss of ignition, lithostratigraphy and $A M S{ }^{14} \mathrm{C}$ measurements of lake sediments and peat deposits accumulated in the former crater lake of Steregoiu (Gutâiului Mts., NW Romania), gave new and important information about vegetation and climate changes from the period GS-2 to the present. During the Lateglacial, three cold events were recorded: before 14,700 cal. years BP (GS-2), 14,05013,800 cal. years BP (GI-1d), 12,900-11,500 cal. years BP (GS-1), and a warm climatic event between 13,800-12,950 cal. years BP (GI-1c to GL-1a). The Late Glacial/Holocene transition around 11,500 cal. years BP, was determined by an expansion of Betula, Alnus and Picea, followed by a rapid and strong expansion of Ulmus. At 10,700 cal. years BP, dense and highly diverse forests with Ulmus, Quercus, Tilia, Fraxinus and a few Acer and Corylus individuals dominated the area. Corylus and Picea were the dominant species in the forests from 10,150 to 8,500 cal. years BP. The first occurrence of single Fagus pollen grains was around 8,000 cal years BP. Only at 4,700 cal year BP Fagus and Carpinus became widespread and established trees in the local woodlands.
\end{abstract}

Keywords: Vegetation dynamic, Late Glacial-Holocene, pollen, AMS ${ }^{14} \mathrm{C}$, SIRM, magnetic susceptibility, LOI, Steregoiu, Gutâi Mts., Romania.

\section{INTRODUCTION}

The aim of this paper is to present a detailed paleoecological reconstruction of the Late Glacial and Holocene vegetation and climate history in the Gutâiului Mountains and to compare this record with other data from Romania. High-resolution pollen analyses were performed in order to study local long-term vegetation dynamics, to detect glacial refugia of deciduous trees, and to establish a chronology of the immigration and expansion of tree species at the Late Glacial/Holocene transition as a response to climatic change. Apart from pollen analysis we used other paleoenvironmental methods in order to improve the interpretation of the past environment. Thus, loss on ignition (hereafter LOI) was performed to determine the organic production at the time when the sediment was deposited. Magnetic measurements (SIRM and susceptibility) were used to aid the visual correlation of individual cores, and to detect the amount of inorganic allochtonous material in the basin, and also to characterize the composition of the magnetic minerals. AMS ${ }^{14} \mathrm{C}$ measurements on terrestrial plant macrofossils enabled to establish the chronology of the sediments.

\footnotetext{
${ }^{1}$ Group for Quaternary Research, Department of Geology, "Babeş-Bolyai" University, Kogălniceanu 1, 3400 Cluj-Napoca, Romania.

${ }^{2}$ Department of Quaternary Geology, University of Lund, Tornavägen 13, 22363 Lund, Sweden.
} 
Quaternary paleoenvironment reconstruction in Romania is based mostly on pollen analyses (Pop, 1932, 1942; 1960; Diaconeasa; 1995; Lupşa, 1980; Buz, 1999; Fărcaş, 1999, 2001). Only in the last decade have new modern methods been utilize in an attempt to better understand Quaternary events (Onac \& Lauritzen, 1996; Björkman et al., 2001; Onac et al., 2001; Wohlfarth et al., 2001). No published information about Quaternary glacial deposits exists for the study area. According to Woldstedt (1958), alpine glaciers did not reach below 1600 m. a.s.l. in the Carpathians during the Last Glacial Maximum. Thus, Romania could probably support a glacial refuge for different trees species. The presence of scattered pollen grains or low percentages of deciduous trees, such as Quercus, Ulmus, Tilia, and Corylus during the Late Glacial were found in few places in Romania and have been attributed to contamination during coring, redeposition, or long distance transport (Buz, 1999; Fărcaş, 1999). Only the southern and southeastern part of Romania is accepted as being glacial refuges for some deciduous tree taxa as Ouercus, Tilia and Fraxinus. Other deciduous trees, Salix, Betula, and Alnus are constantly being recorded in Late Glacial deposits, and are known as "cold resistant species". Together with these species, coniferous trees (Pinus and Picea) were also common. The rapid establishment and expansion of deciduous trees at the beginning of the Holocene implies that glacial refuges were not located far from Romania, or may have existed within Romania.

In this area several sites were investigated by means of pollen analysis. Romania has one of the longest traditions of palynological work in Europe. Earlier investigations have been concentrated mostly on Holocene forest history. Moreover, little has been done with respect to Late Glacial vegetation dynamics and climate. Pollen analyses have been performed with very low resolution (often more than $10 \mathrm{~cm}$ between samples) and none have been supported by radiocarbon dates (Pop, 1932, 1942; 1960; Lupşa, 1980). These authors have established the chronologies of the pollen diagrams by comparison with the German chronology proposed by Firbas $(1949,1952)$ for central and Eastern Europe. Instead this multidisciplinary study enables comparison of the Romanian paleoenvironment with well-dated sequences from western and northwestern Europe (Björkman et al., 2001; Wohlfarth et al., 2001).

\section{STUDY AREA}

The study site, Steregoiu crater $\left(47^{\circ} 48^{\prime} 48^{\prime \prime} \mathrm{N}, 23^{\circ} 32^{\prime} 41^{\prime \prime} \mathrm{E}\right)$ is situated in the northwestern part of Romania, on the western flank of the volcanic Gutâiului Mountains at an altitude of ca. 800 m.a.s.l (Fig. 1.). This massive belong to the western extremity of the Eastern Carpathian mountain chain. The bedrock consists of volcanic rocks, mainly andesites rich in pyroxene and quartz.

The present climatic conditions in this region are continental-temperate (cold and humid). The massif is highly forested and has narrow and long valleys. Its southern slope receives high quantities of solar radiation, being at the same time protected from strong winds coming from west and north. Sometimes, warm air masses come from the Pannonian steppe, therefore making it possible for Mediterranean species, such as Castanea sativa to grow in Romania. 


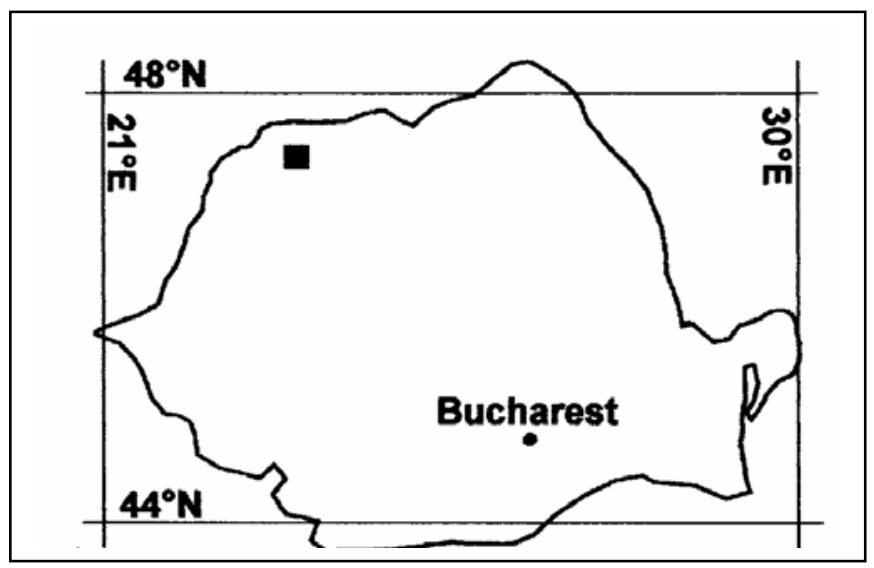

Fig. 1. Location of the Steregoiu crater site

The mean annual temperature is $2-4^{\circ} \mathrm{C}$ high up in the mountains and $7-8^{\circ} \mathrm{C}$ in depresionary zone. The mean winter temperature is $3.5^{\circ} \mathrm{C}$, and mean summer temperature is $12-14^{\circ} \mathrm{C}$. The area has a high humidity, the precipitation's is around $900 \mathrm{~mm} / \mathrm{yr}$, but could sometimes rise to $1200-1400 \mathrm{~mm} / \mathrm{yr}$. (Istvan et al., 1990; Mac \& Budai, 1992). The crater has an elongate surface of 0,5 ha and is drained by a small stream towards the east. The site lies within the beech (Fagus silvatica) forest belt in which rarely Betula verrucosa, Acer pseudoplatanus and Carpinus betulus can be found. The vegetation on the surrounding slopes consists of young beech (Fagus) forest, In addition spruce (Picea) trees can be found around the site, that is now swamp of a eumesotrophic character, where the mire vegetation consists mainly of grasses, sedges, herbs and mosses.

\section{METHODS}

Sample collection was performed with a Russian peat sampler (length: $1 \mathrm{~m}$; diameter: $5 \mathrm{~cm}$ ). Six overlapping cores were collected from the central part of the site. The cores were preliminary described in field. Laboratory work was performed at the Department of Geology in Lund, Sweden.

In the laboratory, the core surfaces were cleaned carefully in order to avoid contamination and described in detail. The cores were sub-sampled continuously at 2-cm interval for pollen analysis, magnetic analysis, LOI, and at 4-cm intervals for plant macrofossil studies.

The samples were dried at $40^{\circ} \mathrm{C}$, in order to calculate magnetic susceptibility and Saturation Isothermal Remanent Magnetization (SIRM). Magnetic susceptibility was measured in a low magnetic field of $0.1 \mathrm{mT}$ using a balanced alternating current bridge circuit. Mass specific units were calculated and expressed as $\mu \mathrm{m}^{3} \mathrm{~kg}^{-1}$. SIRM was induced in a strong magnetic field of 1 Tesla by a Redcliff BSM 700 Puls Magnetic Charger. This magnetic field is strong enough to saturate the samples. The resulting remanent magnetization was measured with a Molspin Spinner Magnetometer. Mass specific units were calculate as $\mathrm{mAm}^{2} \mathrm{~kg}^{-1}$. SIRM reflects 
the concentration, composition and grain size distribution of magnetic minerals in the sample, however only minerals that are capable of holding a remanence will contribute to this signal (Sandgren \& Snowball, 1999; Thomson \& Oldfield, 1986).

LOI was estimated following the methods described by Bengtesson \& Enell (1986). The samples were placed in crucibles with a known weight, dried over night at $100^{\circ} \mathrm{C}$, cooled and weight. The samples were then ashed at $550^{\circ} \mathrm{C}$ for 3 hours, cooled and weight again. Previous research as showed that carbonates are not present in the sediments. LOI was used for estimating the amount of organic matter and is present as the percentage of the weight of the dried sample.

For pollen analysis, $258 \mathrm{sub}$-samples with $1 \mathrm{~cm}^{3}$ of volume were taken. Five Lycopodium tablets with a known number of spores were added to each sample in order to determine the concentration of fossil pollen. The chemical preparation for pollen analysis follows the standard methods of Berglund and Ralska-Jasiewiczowa (1986) and Moore et al. (1991). The slides were mounted in glycerine. Pollen counts were normally made at $400 x$ magnification, whereas $1000 x$ were used for some critical determinations. Pollen identification follows the keys and illustrations in Moore et al. (1991), Reille (1992) and Faegri et al. (1989). In addition, the pollen reference collection at the Department of Geology, Lund University, was also used to check several types. Between 500 and 700 pollen grains were counted in most of the samples, except in the ten bottom most samples, were a sum of 300 grains was excepted due to low pollen concentration. The calculation of pollen percentages is based on the total sum of terrestrial pollen taxa. The pollen diagram was constructed with the TILIA computer program (Grimm, 1987, 1991).

AMS ${ }^{14} \mathrm{C}$ measurements were performed on terrestrial plant macrofossils. Seventeen samples were dated by the AMS facility in Uppsala, Sweden.

\section{RESULTS}

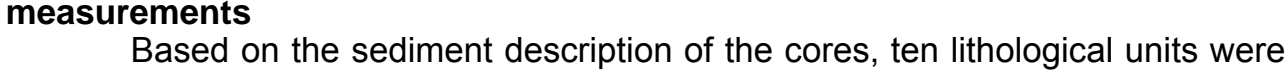
described (Table 1). The measurements of magnetic susceptibility, SIRM and carbon content are presented in Figure 2.

Unit 1 in the bottom-part of the sequence is composed of reddish brown silty clay with sandy and gravely layers. SIRM starts with high values, but decreases from 27.192 to $3.3 \mathrm{mAm}^{2} \mathrm{~kg}^{-1}$ towards the top. A few isolated peaks occur due to sandy and gravely layers. Magnetic susceptibility decreases from 1.8 to $0.22 \mu \mathrm{m}^{3} \mathrm{~kg}^{-1}$ and $\mathrm{LOI}$ is around $8 \%$.

Unit 2 is composed of gyttja clay with different colors. SIRM has a maximum values of $2.49 \mathrm{mAm}^{2} \mathrm{~kg}^{-1}$, and magnetic susceptibility is $0.14 \mu \mathrm{m}^{3} \mathrm{~kg}^{-1}$. LOI shows a slight, but distinct increase to $14.4 \%$.

Unit 3 consists of grayish brown silt, and slightly sandy and gravely layers with an erosive lower boundary. In comparison with previous zone, SIRM values show an increase to $5.6 \mathrm{mAm}^{2} \mathrm{~kg}^{-1}$, and magnetic susceptibility to $0.34 \mu \mathrm{m}^{3} \mathrm{~kg}^{-1}$, while LOI decreases to $12 \%$.

Unit 4 consists of clay and gyttja with visible macrofossils. Susceptibility decreases throughout the unit. SIRM shows decreasing values up to the middle of 
the unit, but increases again toward the top to $2.4 \mathrm{mAm}^{2} \mathrm{~kg}^{-1}$. LOI increases to $18 \%$, and upwards to $99 \%$ in the middle part.

Unit 5 is composed of grayish gyttja. SIRM and susceptibility values show a slight increase and the LOI remains constant.

Unit 6 is composed of brown gyttja. SIRM and susceptibility value decrease and LOI increases slightly to $25 \%$.

Unit 7 is composed of dark brown, coarse detritus gyttja with wood fragments. SIRM and susceptibility values are low and LOI increase to $62 \%$, but decreases again to $40 \%$ in the upper part.

Unit 8 consists of dark brown, drift gyttja. SIRM and susceptibility values are low and LOI increases from $66 \%$ to $92 \%$.

Unit 9 is composed of dark brown, carr peat with alternations of more and less humidified layers. SIRM and susceptibility values are low and LOI fluctuates from 77 to $99 \%$.

Unit 10 is a dark brown fen peat with low, medium, and highly humidified horizons. The LOI ranges from 72 to $99 \%$.

\begin{tabular}{|c|c|c|}
\hline Unit & Depth below surface (m) & Description \\
\hline 10 & $\begin{array}{c}0.07-0 \\
0.11-0.07 \\
0.255-0.11 \\
125-25.5 \\
\end{array}$ & $\begin{array}{l}\text { Medium humidified brown, fen peat } \\
\text { Medium to low humidified reddish brown, fen peat } \\
\text { Medium humidified reddish brown, fen peat } \\
\text { Dark brown, highly humidified fen peat }\end{array}$ \\
\hline 9 & $2.80-1.255$ & $\begin{array}{l}\text { Dark brown carr peat with more humidified and less } \\
\text { humidified parts }\end{array}$ \\
\hline 8 & $2.865-2.80$ & Dark brown, transition "drift gyttja", g LB \\
\hline 7 & $\begin{array}{l}3.35-2.865 \\
3.715-3.35 \\
4.115-3.715 \\
4.28-4.115 \\
\end{array}$ & $\begin{array}{l}\text { Dark brown coarse detritus gyttja } \\
\text { Dark brown, very coarse detritus gyttja with large wood } \\
\text { fragments g LB } \\
\text { Dark brown, very coarse detritus gyttja, g LB } \\
\text { Brown, coarse detritus gyttja, g LB }\end{array}$ \\
\hline 6 & $4.57-4.28$ & Brown, gyttja, g LB \\
\hline 5 & $4.663-4.57$ & "Transition" Dark gray, gyttja \\
\hline 4 & $\begin{array}{c}4.82-4.663 \\
4.3-4.82 \\
5.108-4.93 \\
5.225-5.108\end{array}$ & $\begin{array}{l}\text { Lighter greyish, brown clay gyttja, g LB } \\
\text { Grayish brown, clayey gyttja, s LB } \\
\text { Lighter greyish brown, clayey gyttja, g LB } \\
\text { Grayish brown, clayey gyttja, g LB, visible macrofossils }\end{array}$ \\
\hline 3 & $5.26-5.225$ & Grayish-brown, silty, slightly sandy and gravel erosive LB \\
\hline 2 & $\begin{array}{l}5.35-5.26 \\
5.38-5.35 \\
5.405-5.38 \\
5.44-5.405 \\
\end{array}$ & $\begin{array}{l}\text { Grayish brown, gyttja -clay, g LB } \\
\text { Reddish brown, gyttja clay, s LB } \\
\text { Bluish brown, gyttja clay, g LB5 } \\
\text { Reddish brown, gyttja clay, g LB }\end{array}$ \\
\hline 1 & $\begin{array}{c}5.70-5.44 \\
5.84-5.70 \\
5.88 / 87-5.84 \\
5.925-5.88 / 87\end{array}$ & $\begin{array}{l}\text { Reddish brown, partly laminated silty clay, g LB } \\
\text { Reddish brown, slightly clayey sandy silt with gravel, s LB } \\
\text { Reddish, silty clay, sandy gravelly layers at } 584,5, \mathrm{~s} \text { LB } \\
\text { Brown reddish, silty clay with gravel }\end{array}$ \\
\hline
\end{tabular}

Table 1. Lithostratigraphic description of the Steregoiu core (LB = layer boundary; $\mathrm{s}=$ sharp; $\mathrm{g}=$ gradual). 

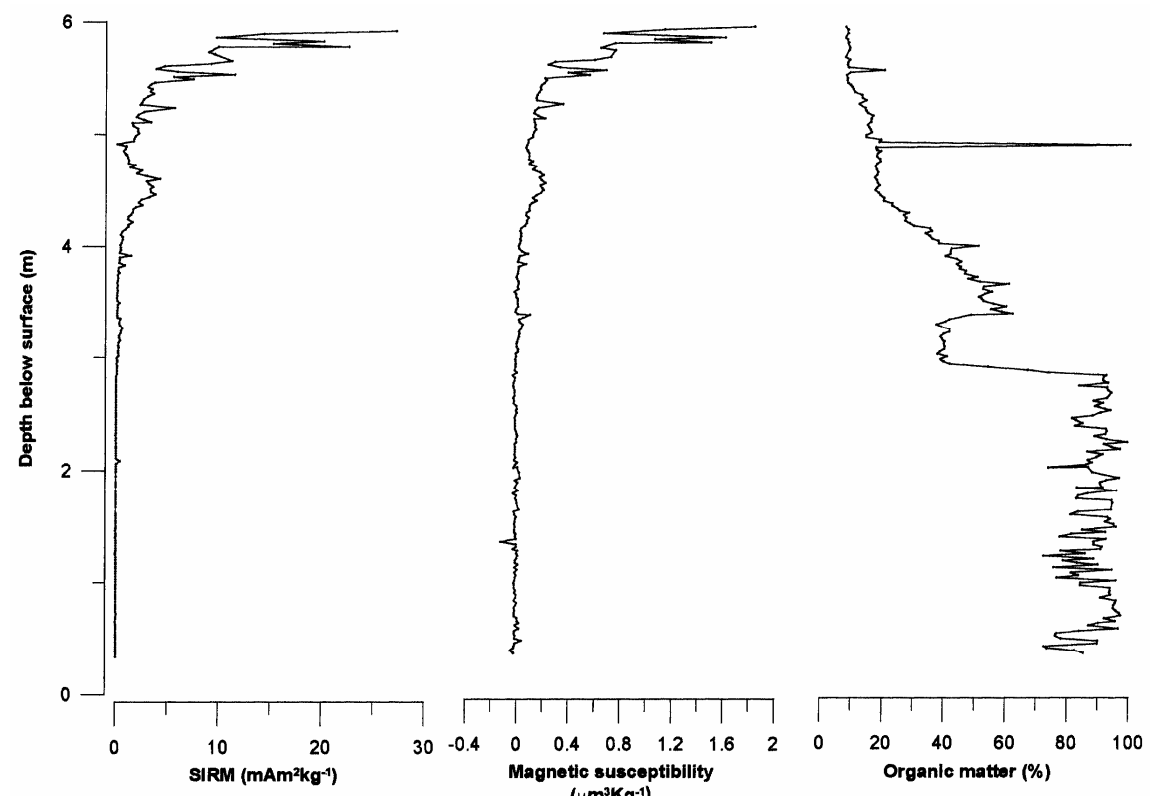

Fig. 2. SIRM, magnetic susceptibility and organic matter (loss of ignition) of the Steregoiu core sediments.

\section{Chronology}

The AMS ${ }^{14} \mathrm{C}$ measurements were converted into calibrated years $\mathrm{BP}$, using the radiocarbon calibration curve (Stuvier et al., 1998). Based on the calibrated dates, an age depth curve was established. From this curve accumulation rates of the sediments were estimated (Fig. 3). This rate is calculated to 41.3 years $/ \mathrm{cm}$ of in the inorganic sediments (between 5.43-4.67 m), 15.2 years $/ \mathrm{cm}$ in the gyttja (between 4.67-2.80 m). In the peat, the accumulation rate is about 9.5 years $/ \mathrm{cm}$ (in carr peat between $2.80-1.80 \mathrm{~m}$ ), 66.2 years $/ \mathrm{cm}$ in the upper part of carr peat (between 1.80-1.255 $\mathrm{m}$ ), and 31 years/cm in the fen peat $(1.255-0 \mathrm{~m})$.

\section{Pollen stratigraphy}

The pollen data are presented in a percentage diagram with all terrestrial pollen types included in the calculation sum (Fig. 3). The pollen taxa are plotted against depth and an interpolated age. To facilitate the description and interpretation of the pollen diagram, nineteen local pollen assemblages zones (LPAZ S1-S19) have been established (Table 2). These zones have been established visually, and each zone boundary denotes significant changes in pollen deposition and hence, major chances in vegetation cover. 
A PALEOECOLOGICAL RECONSTRUCTION OF THE LATE GLACIAL AND HOLOCENE ...

Table 2. Pollen stratigraphy.

\begin{tabular}{|c|c|c|c|c|}
\hline Age & Depth & $\begin{array}{c}\text { Sedimentary } \\
\text { units }\end{array}$ & $\begin{array}{l}\text { Pollen } \\
\text { zones }\end{array}$ & Dominating pollen types \\
\hline $0-300$ & $0.14-0.005$ & 10 & 19 & Fagus - Poaceae - Quercus \\
\hline $300-1050$ & $0.39-0.14$ & 10 & 18 & Fagus-Quercus - Carpinus \\
\hline $1050-2.200$ & $0.73-0.39$ & 10 & 17 & Fagus - Poaceae - Carpinus \\
\hline $2.200-3.400$ & $1.11-0.73$ & 10 & 16 & Fagus-Picea-Carpinus \\
\hline $3.400-4.800$ & $1.41-1.11$ & 10 & 15 & Corylus - Picea-Fagus \\
\hline $4.800-7.500$ & $1.89-1.41$ & 9 & 14 & Corylus - Picea - Ulmus - Quercus \\
\hline $7.500-8.200$ & $2.5-1.89$ & 9 & 13 & Corvlus - Picea-Ulmus - Filipendula \\
\hline $8.200-8.600$ & $2.82-2.5$ & 9 & 12 & Corylus-Picea-Ulmus \\
\hline $8.600-9.300$ & $3.35-2.82$ & 7,8 & 11 & Corylus-Ulmus - Picea \\
\hline $9.300-10.200$ & $3.98-3.35$ & 7 & 10 & Ulmus-Corvlus-Picea \\
\hline $10.200-10.750$ & $4.36-3.98$ & 6,7 & 9 & Ulmus - Picea-Fraxinus \\
\hline $10.750-11.250$ & $4.59-4.36$ & 6 & 8 & Ulmus-Pinus - Betula \\
\hline $11.250-11.500$ & $4.69-4.59$ & 5 & 7 & Pinus - Betula - Alnus \\
\hline $11.500-12.600$ & $4.99-4.69$ & 4 & 6 & Pinus - Artemisia - Poaceae \\
\hline $12.600-12.950$ & $5.09-4.99$ & 4 & 5 & Betula - Pinus - Alnus \\
\hline $12.950-13.750$ & $5.25-5.09$ & 4 & 4 & Betula-Pinus-Picea \\
\hline $13.750-14.150$ & $5.32-5.25$ & 2,3 & 3 & Pinus - Almus Betula \\
\hline $14.150-14.700$ & $5.44-5.32$ & 2 & 2 & Pinus - Poaceae - Betula \\
\hline$>14.700$ & $5.92-5.44$ & 1 & 1 & Pinus - Poaceae - Artemisia \\
\hline
\end{tabular}




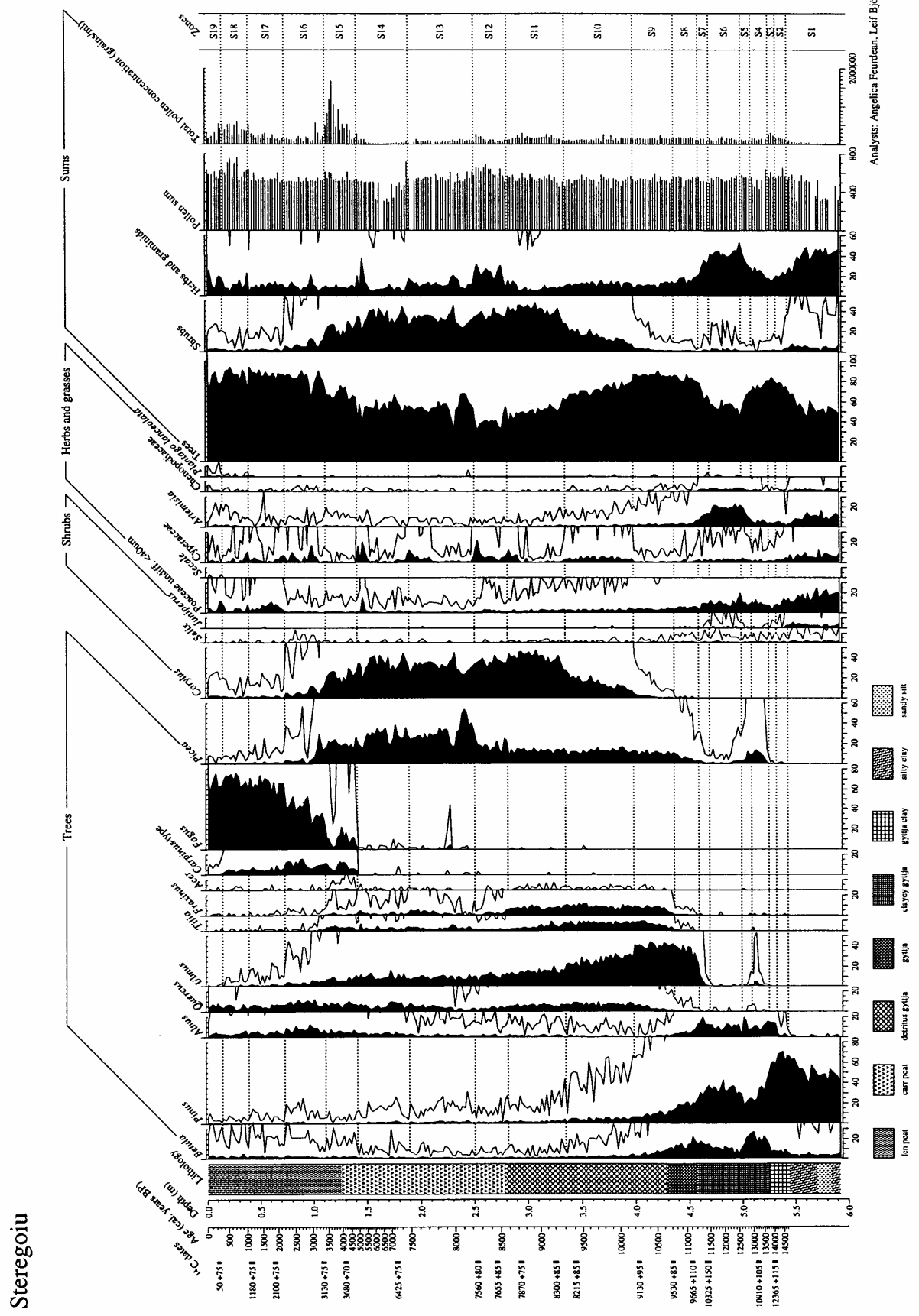

Fig. 3. Percentage pollen diagram of selected taxa from Steregoiu. 


\section{DISCUSSION}

\section{Reconstruction of the sedimentary history}

The sediments from Steregoiu extend more than 14700 cal. years BP back in time. The infilling of the Steregoiu crater was made by allochtonous material (clay and sand), and by autochthonous material (as gyttja and peat). The bottom sediments, below $5.44 \mathrm{~m}$ contain inorganic and compact sediments. They were probably they were deposited due to slope erosion, and strong winds in a mainly dry climate. Between $5.44 \mathrm{~m}$ to $5.26 \mathrm{~m}$, the sediment becomes more organogenic as gyttja clay was observed in the lake. Increasing amounts of organogenic material suggests higher productivity in the lake, but still made shallow conditions. Between $5.26-4.57 \mathrm{~m}$ an increase of inwashed minerogenic material, is recorded, as clayey gyttja was deposited. From $4.57 \mathrm{~m}$ to $2.80 \mathrm{~m}$, gyttja with a more or less coarse content (particularly wood fragments) was deposited. High values of organic material record an increase in lake productivity. From $2.80 \mathrm{~m}$, the lake had been infilled with sediments and carr peat. The most common carr species were Alnus, Betula, Salix, sedges, grasses and herbs, such as Filipendula, Lysimachia, Ranunculaceae and Equisetum were also common. At $1,25 \mathrm{~m}$ to the top fen peat replaced carr peat.

\section{Reconstruction of the vegetation development and climate change}

\section{$>14,700$ cal. years BP}

During this period the vegetation in the area had an open structure. The vegetation was a mosaic with areas dominated by low shrubs, such as Salix, Juniperus, and Betula, and areas dominated by grasses, sedges and herbs, such as Artemisia, Chenopodiaceae, Helianthemum, Asteraceae, Caryophyllaceae and Ranunculaceae. With Pinus percentages represented around $50 \%$ it is difficult to interpret these values as indicating a local presence. Pinus is known as a species which produces enormous amounts of pollen, which can be, transported very long distances. Usually percentages values above $20 \%$ can be attributed to a local presence (Huntley, 1983). Most likely, Pinus had a regional presence in valleys at lower altitudes with favorable microclimate. Scattered areas with little or novegetation around the site. Low pollen concentration and minerogenic sediments indicate this fact. Strong winds and slope erosion during the end of the Full Glacial period (GS-2) caused the transfer of large amounts of allochtonous material into the crater (Fig. 2).

\section{$14,700-14,050$ cal. years BP}

During this period open boreal forest dominated by Pinus and Betula expanded. Open vegetation with shrubs (mainly Salix and Juniperus) and herbs, such as Poaceae, Cyperaceae, Artemisia, Chenopodiaceae, Asteraceae and Ranunculaceae were also common in the area. Pinus has its highest values during this period. This certainly must indicate that Pinus expanded regionally, as well as locally, simultaneously as the open vegetation diminished. Alnus was common around the basin. The development of a denser vegetation cover corresponds with a warm event at the beginning of the Late Glacial (Gl-1e in the GRIP ice core stratigraphy). 


\section{$14,050-13,800$ cal. years BP}

There is strong evidence for a development of a rather open forest type during this period. Pinus percentages had become lower at the same time as herb pollen values have increased. Very high pollen values of Alnus and Betula can most likely assigned to local occurrences in the vicinity of the basin. The increase of minerogenic input into the basin may be the effect of a reduction in vegetation cover as a response to a colder climate (GL-1d, in the GRIP ice core stratigraphy).

\section{3,800-12,600 cal. years BP}

The vegetation during this period was dominated by coniferous trees, such as Pinus and Picea, but, deciduous trees, such as Betula, Ulmus and Alnus were also abundant. Picea is recorded by pollen values with a maximum of around $15 \%$, indicating it was an important component in the forests. Knowing that values of 20 $30 \%$ are usually suggesting a local presence (Tzedakis, 1993). Ulmus has a short and rapid appearance, and reaches maximum values of $5.3 \%$. Ulmus pollen percentage above $2 \%$ is commonly attributed as indicative for a local presence (Huntley, 1983). Ulmus and Picea showed rapid expansions that could suggest that their glacial refugia was close to the studied area. Intriguing is the presence of scattered or single pollen grains of other deciduous trees, such as Quercus, Fraxinus and Tilia. Most like their presence is due to long distance transportation. Areas with open vegetation were present in the region, but were probably confined to higher elevations. The expansion of tree vegetation likely corresponds to a warmer climatic phase, which in time corresponds approximately to $\mathrm{Gl}-1 \mathrm{c}-\mathrm{GI}-1 \mathrm{a}$ in the GRIP event stratigraphy.

\section{$12,600-11,500$ cal. years BP}

This period is characterized by a re-expansion of open vegetation communities around the basin. The open vegetation was mainly dominated by herb species, such as Poaceae, Artemisia, Chenopodiaceae, Asteraceae Tubuliflorae, Asteraceae Liguliflorae and Helianthemum, and low shrubs, such as Juniperus and Salix. Most likely, Betula individuals also occurred. Un-vegetated areas and unstable ground were probably widespread in the area. The forest around this area was reduced by the colder climate, some trees probably still occurred in the region, at lower altitude but, only on favourable sites in valleys.

The high percentages for herbaceous taxa, particularly Artemisia and Chenopodiaceae, the reduction of trees and increased accumulation of inorganic material, are a clear signal for the cool phase known as GS-1 (Younger Dryas).

\section{$11,500-10,700$ cal. years BP}

At the Late Glacial/Holocene transition Betula and Pinus expanded and formed open forests. Ulmus and Picea probably had scattered occurrences at the beginning of this period, but at ca. 11,250 cal. years BP they rapidly expanded becoming the dominant trees in the forest canopy. The sudden and large increase of Ulmus (from scattered pollen grains to values around $40 \%$ ) may indicate it had survived during the Late Glacial in the close vicinity from where it could rapidly expand during the early Holocene. Previous palynological records from Romania 
show similar patterns of vegetation development in early Holocene (Farcas et al., 1999; Buz, 1999). Approximately $100 \mathrm{~km}$ to the west from our study area, at Bartoliget Marsh site (Hungary), strong reduction of coniferous trees and expansion of deciduous woodland marked the Late Glacial/Holocene transition. Tilia dominated, followed by an expansion of Quercus. The evolution in Hungary it is very different from our findings. This situation was probably caused by differences in altitude and regional climate. The high values of herbs and shrubs pollen types indicate areas with open vegetation still occurred in the region, but were confined to higher altitudes. Between 11,250-10,700 cal. years BP the density of Ulmus woodland increased while herb pollen values significantly decreased.

\section{$10,700-8,600$ cal. years BP}

From 10,700 cal. years BP onwards, the forest in the area was of a speciesrich nemoral type. Ulmus was the dominant tree, but Quercus, Fraxinus and Tilia had also become established and started to expand in the region. The low but continuous presence of Acer pollen grains suggests it occurred locally. Around 10,750 cal. years BP Corylus had a slight presence in region. Later Corylus it significantly expanded, simultaneously Ulmus was reduced. Over a period of 1,300 years a mixed deciduous forest type developed, where Ulmus and Corylus were dominant species. Around 9,300 cal. years BP Corylus reached its maximum abundance in the forests.

\section{$8,600-4,800$ cal. years BP}

Around 8,600 cal. years BP an important change in the forest composition is indicated by a significant expansion of Picea at the expanse of Corylus. For a short period (around 250 years) Picea had high percentages mirrored by lower values for Corylus. Most of the broad leaves trees, such as Tilia, Quercus and Fraxinus, show slight declines. Only Ulmus has more or less constant frequencies throughout this period.

The regular presence of Acer pollen grains, suggests that loccally it was probably common. Fagus pollen grains occurr regularly from around 8,100 cal. years BP. Fagus also shows an isolated peak value around 7,900 cal. years BP. At this point, Fagus has percentages that are high enough to indicate a local presence. However, Fagus seems to have failed to establish a larger population in the area, and appears to have diminished quite soon. The pteridophytes are well represented in the pollen samples, and often clumps of spores, or sporangia with attached spores are found. Most likely, pteridophytes were important in the field layer of the forest. Few areas with open vegetation in the region existed.

\section{4,800-3,300 cal. years BP}

During this period, a dense mixed forest type with many tree and shrub taxa, such as Quercus, Ulmus, Fraxinus, Acer, Carpinus, Fagus, Tilia, and Corylus occurred in the area. Corylus and Picea were still dominant in the forest, however Fagus and Carpinus had become established and had started to expand in forest. 
Carpinus seems to have established and expanded at the same time as Fagus. Around 3,300 cal. years BP Fagus became the dominant tree in the canopy. This development is in good agreement with Lupsa's study (1980). Pop (1943) also found an early and abundant presence of Fagus in the Oas-Maramures area. $\mathrm{He}$ suggested that this area could have supported glacial refugia. Our pollen data does not show a presence of Fagus during the Late glacial, but its presence in this area is recorded earlier than in other regions of Romania. The appearance of Carpinus happened however, later in study area, when compared to other regions in Romania. In northeastern Romania Carpinus expanded around 5,500 cal. years BP. In the southeastern part of the country (close to the Black Sea) it started to expand at the beginning of the Holocene. Single or scattered pollen grains of Plantago lanceolata, Rumex acetosa/R. acetosella and Urtica may be interpreted as signs of a local human influence on the vegetation.

\section{3,300-2,200 cal. years BP.}

The composition and structure of the forest changed dramatically during this period. Fagus was the dominant tree in the forest, but Carpinus and Quercus were also common. Quercus and Carpinus most likely dominated the woodlands at lower altitudes, while Fagus occurred at higher elevations together with Picea. The presence of Ulmus, Tilia and Fraxinus were strongly reduced and they never attained higher values again. Most likely they were rare in the forest comparing with today situation. Corylus occurred with low values in the shrub layer. The regularly presence of Abies pollen grains in the upper part of period may suggest that Abies occurred in the region, but it was certainly not present near the study site. Previous investigations by Pop (1943) showed that Abies had minimum poor presence during the period whereas Fagus had maximum values. He postulated that the Fagus-Abies community is new, and has originated during the late Holocene. During the Quaternary period, the dynamics of these taxa have followed different pathway. The field layer in the forest may have been dominated by pteridophytes.

\section{2,200-0 cal. years BP}

During the last 2,200 years, the forest in the area was dense and dominated by Fagus, in addition but some Quercus and Carpinus individuals did occur. The Fagus dominance is extraordinary, its pollen percentages reaching values up to $75 \%$. This dominance reduced the species diversity in the forest, most of the nemoral trees, such as Ulmus, Tilia and Fraxinus were out-competed by Fagus.

From 300 cal. years BP to the present small change in the forest occurred, as Carpinus became less common. Corylus shows a slightly increasing trend during the last few hundred years, and was probably favoured by human influence. This is the first period where the pollen data indicate a significant influence of humans in area. For instance, the first evidence of cultivated cereals, such as Hordeum and Secale, appear however, with very low pollen values. There are other indicators of human influence. For example, pollen grains indicating pasture and fallow land, i.e. Juglans-type, Poaceae undiff. $>40 \mu \mathrm{m}$, Plantago lanceolata, Chenopodiaceae, Rumex acetosa/R. acetosella, Artemisia, Cannabis-type and Urtica. Some of these pollen types have appeared earlier in our site but, only during this period does their 
percentages show increasing trends. Increases of Poaceae $<40 \mu \mathrm{m}$ and Artemisia in the region may indicate areas with expanded open vegetation. These open areas were possibly uses for grazing. Today, the open vegetation, including the forest, is successfully used for grazing. The surface vegetation of the mires dominated by Poaceae (particularly Molinia and Glyceria), are used by farmers in order to provide hay to feed domestic animals.

\section{CONCLUSIONS}

The multidisciplinary analyses of Steregoiu shows that the sediments in the former crater lake cover a time span of over 14,700 years (Fig. 4).

The bottom sediments, which were deposited $>14,700$ cal. years BP, belong to the Last Glacial Maximum. The Last Glacial Maximum is equivalent with GS-2 in the GRIP ice core event stratigraphy (Björck et al., 1998; Walker et al., 1999). These sediments were minerogenic and poor in pollen. Most of the pollen deposited during this time belongs to the herbs, grasses, sedge, and shrubs, such as Artemisia, Chenopodiaceae, Asteraceae, Ranunculaceae, Salix, Juniperus and Ephedra. Pinus and Betula have fairly high percentages of pollen. These high percentages indicate, Pinus and Betula but were present in the area but most likely occurred in lower altitudes.

The climatic events during the Late Glacial (14.700-11.500 cal. years BP) are well expressed in the vegetation development. Successions of cold (GI-1d, GS-1) and warm episodes ( $\mathrm{Gl}-1 \mathrm{e}, \mathrm{Gl}-1 \mathrm{c}, \mathrm{Gl}-1 \mathrm{a})$ have had an immediate response in vegetation cover and lithostratigraphy. During cold phases, herbs, grasses, sedges and low shrubs dominated areas of widespread open vegetation. During climatically more favorable phases, this vegetation type was replaced by open woodlands containing Betula, Pinus, Picea and Alnus.

Open forest with Betula, Picea, Pinus and Ulmus developed around the site during the warm phase (GI-1c-1a), indicated in the GRIP ice core event stratigraphy between 13,800-12,950 cal. years BP. The appearance of Ulmus during this period is remarkable (it reaches a maximum of c. $5 \%$ ). Most likely, Ulmus must have been present on glacial refugia not far from the study area, otherwise, it could not have responded quickly to the warmer conditions. Besides Ulmus, Picea, Betula and Alnus must have been surviving in the area during the Late Glacial. For the same period high percentages of Picea were recorded by Wohlfarth et al. (2001). In addition, Wohlfarth's study include macrofossils that clearly shows the presence of Picea, Pinus ( $P$. sylvestris, $P$. mugo, P. cembra), Populus, Larix, Betula, Juniperus and Salix. Glacial refugia for Picea (at 11,140 BP) is also confirmed by Farcas et al. (1999) in their studies of high altitude sites in the northeast and southwest of the Carpathians Mountains. The cooling signal of the GS-1 (Younger Dryas), between 12,950-11,500 cal. years BP, is clearly recorded in our sediments. The cooling is expressed by a reduction in the tree vegetation, which was eventually replaced by herbs, sedges, and shrubs, particularly Artemisia, Chenopodiaceae and Poaceae, respectively.

At the Late Glacial/Holocene transition (around 11,500 cal. years BP), Betula and Alnus expand slightly later, and Picea and Ulmus became established. At 11,250 cal. years BP, Ulmus became the dominant trees in the forest. The rapid 
response of Ulmus to the climatic amelioration at the transition to the Holocene suggests that it must had survived on a refugia not very far from the study site. Slightly later, deciduous trees, such as Quercus, Fraxinus and Tilia appeared and expanded. Only at 10,500 cal. years BP they had they become abundant in the forest. From 10,500 cal. years BP onward, a dense mixed forest containing UImus, Quercus, Tilia, Fraxinus, Picea a few Corylus and Acer occurred in the area. Corylus expended further in the area around 9,300 cal. years BP. At 8,600 cal. years BP Picea had become co-dominant with Corylus, when the broad leaves species were considerably reduced in the forest. This type of vegetation dominated the area until 4,800 cal. years BP when Fagus and Carpinus became established and rapidly expanded in the local forest.

The regular presence of Fagus pollen grains start around 8,000 cal years BP, but it was first at c. 4,800 cal. year BP, Fagus suddenly became widespread in the local forest Around 4,000 cal. years BP, Fagus became the dominant tree in the canopy. Fagus has held this dominance until the present day. The presence of Fagus is recorded earlier in other regions of country. For instance, it started to appear around 3,000 years ago in the north-eastern and south-western Carpathians Mountains (Farcas, 1999). Carpinus instead, seems to have occurred later (around 4,700 cal. years BP) in the study site, than in other parts of Romania. Expansion of Carpinus occurred around $5,500 \mathrm{cal}$. years B.P in the north-eastern part of Romania, and in the south-eastern part (close to the Black Sea) at the beginning of the Holocene. Abies only occurred between 3,000-1,500 cal. years $\mathrm{BP}$, indicated by scattered pollen grains.

Signs of human influence on the local vegetation are strong only during the last period from about 300 cal. years BP. At this time the grazing pressure seems to have increased and agriculture may have expanded in the Talna Valley below $500 \mathrm{~m}$ a.s.l. Several pollen grains of cultivated species are found during this period, but they most likely originated from arable fields on lower altitudes. An introduction of forest grazing in the area may have occurred around 1000 cal. years BP, as Plantago lanceolata starts to occur regularly around this time. 
A PALEOECOLOGICAL RECONSTRUCTION OF THE LATE GLACIAL AND HOLOCENE ...

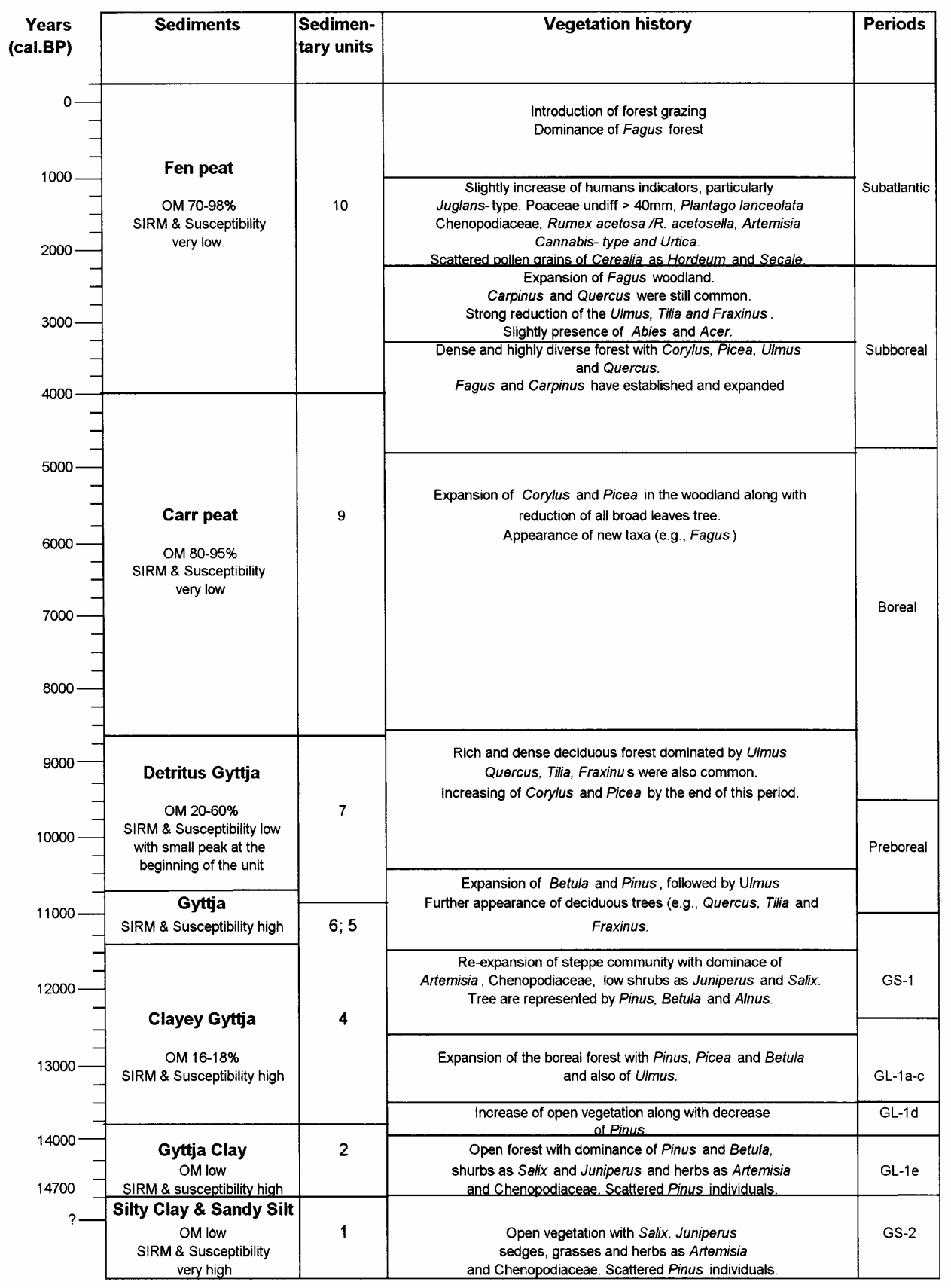

Fig. 4. Summary of the vegetation and environmental history of Steregoiu, based on sediment parameters, pollen and calibrated radiocarbon data (OM: organic matter; SIRM: saturation isothermal remanent magnetization). 


\section{REFERENCES}

Bengtsson, L., Enell, M. (1986), Chemical analysis. In: Berglund, B.E. (Ed.), Handbook of Holocene Palaeoecology and Palaeohydrology, Wiley \& Sons, Chichester, pp. 423-454.

Berglund, B. E., Ralska-Jasiewiczowa, M. (1986) Pollen analysis and pollen diagrams. In: Berglund, B. E. (Ed.), Handbook of Holocene Palaeoecology and Palaeohydrology, Wiley \& Sons, Chichester, p. 455-484.

Björck, S., Walker, M. J. C., Cwynar, L. C., Johnsen, S., Knudsen, K.-L., Lowe, J. J., Wohlfarth, B., INTIMATE members (1998), An event stratigraphy for the Last Termination in the North Atlantic region based on the Greenland ice-core record: a proposal by the INTIMATE group. Journal of Quaternary Science, 13, p. 283-292.

Björkman, L., Feurdean, A., Cinthio, K., Possnert, G. (2001), Late Glacial and early Holocene vegetation development in the Gutaiului Mountains, NW Romania, Quaternary Science Reviews (in press).

Buz, Z. (1999), Cercetări fitosociologice şi palinologice în zona Sovata-Praid-Dealu. Ed. Casa Carții de Ştiința, Cluj Napoca.

Diaconeasa, B., Farcas, S. (1996), Stejărişurile amestecate, evoluția şi dinamica lor în Tardiglaciarul si Holocenul din România. Universitatea "Babeş-Bolyai", Cluj-Napoca, Contributii Botanice, 1995-1996, p. 103-115.

Faegri, K., Iversen, J. (1989), Textbook of pollen analyses ( $4^{\text {th }}$ ed., revised by Faegri, K., Kaland, P.E., Krzywinski, K.). John Wiley, Chichester.

Fărcaş, S., de Beaulieu, J.L., Reille, M., Coldea, G., Diaconeasa, B., Goslar, T., Jull, T. (1999), First ${ }^{14} \mathrm{C}$ datings of Late Glacial and Holocene pollen sequences from the Romanian Carpathians. Comptes Rendues de l'Académie des Sciences de Paris (Sciences de la Vie et de la Terre), 322, p. 799-807.

Fărcaş, S. (2001), Pollen data on the peat bogs in the Căliman Mountains. Doctoral thesis abstract.

Firbas, F. (1949), Spät- und nacheiszeitliche Waldgeschichte Mitteleuropas nördlich der Alpen. Band I. Fischer, Jena, p. 480.

Firbas, F. (1952), Spät- und nacheiszeitliche Waldgeschichte Mitteleuropas nördlich der Alpen. Band II. Fischer, Jena, p. 256.

Grimm, E. (1987), Coniss: a FORTRAN 77 program for stratigraphically constrained cluster analysis by the method of incremental sum of squares. Computers and Geosciences 13: 1337.

Grimm, E. (1991), Tilia 1.12, Tilia Graph 1.18. Springfield, llinois State Museum, Research and Colection Center.

Huntley, B., Birks, H. J. B. (1983), An atlas of past and present pollen maps for Europe: O13.000 years ago. Cambridge University Press, Cambridge, p. 667.

Isvan, D., Popescu, S., Pop, I. (1990), Munții Gutîi. Ed. Sport Turism, Bucureşti, p. 7-30.

Lupsa, V. (1980), Evolutia postglaciara a ecosistemelor forestiere din "Tara Oaşului" (Jud. Satu Mare). Contribuții botanice 5, p. 63-68.

Mac, I., Budai, C. (1992), Munții Oaş-Gutâi-Țibleş. Casa editorială pentru turism şi cultură "Abedona". Bucureşti, p. 7-45. 
Moore, P.D., Webb, J.A., Collinson, M.E. (1991), Pollen analysis (2 ${ }^{\text {nd }}$ ed). Blackwell, Oxford, p. 216.

Onac, B, P., Lauritzen, S. E. (1996), The climate of the last 150,000 years recorded in speleothems: preliminary results from north-western Romania. Theoretical and Applied Karstology 9: 9-21.

Onac, B, P., Constantin, S., Lauritzen, S. E., Lundberg, J. (2001), Isotope-climate record in a Holocene stalagmite from Ursilor Cave (Romania). Journal of Quaternary Science (in review).

Pop, E. (1932), Contribuții la istoria vegetației cuaternare din Transilvania. Bul. Grad. Bot. Cluj. 12 , p. $29-102$.

Pop, E. (1942) Contribuții la istoria pădurilor din nordul Transilvaniei. Bul. Grad. Bot., Cluj, 9, 3-4, p. 81-210.

Pop, E., Boscaiu, N., Ratiu, F., Diaconeasa B. (1960), Mlaştinile de turbă din R.P.R. Ed. Academiei Romane, Bucureşti, p. 511.

Reille, M. (1992), Pollen et spores d'Europe et d'Afrique du nord. Laboratoire de botanique historique et palynologie, Marseille, p. 520.

Stuiver, M., Reimer, P. J., Bard, E., Beck, J. W., Burr, G. S., Hughen, K. A., Kromer, B., McCormac, G., van der Plicht, J., Spurk, M. (1998), INTCAL98 Radiocarbon age calibration, 24,000-0 cal BP. Radiocarbon, 40, p. 1041-1083.

Tzedakis, P.C. (1993), Long-term tree population in northwest Greece through multiple Quaternary climate cycles. Nature, 364, p. 437-440.

Walden, J., Oldfield, F. \& Smith, J.P. (editors) (1999), Environmental Magnetism: a practical guide. Technical Guide, No. 6, p. 35-88. Quaternary Research Association, London.

Walker, M. J. C., Björck, S., Lowe, J. J., Cwynar, L. C., Johnsen, S., Knudsen, K.-L., Wohlfarth, B., INTIMATE group (1999), Isotopic 'events' in the GRIP ice core: a stratotype for the Late Pleistocene. Quaternary Science Reviews, 18, p. 1143-1150.

Willis, K. J., Sümegi, P., Braun, M., Tóth, A. (1995), The late Quaternary environmental history of Bátorliget, N.E. Hungary. Palaeogeography, Palaeoclimatology, Palaeoecology, 118, p. 25-47.

Wohlfarth, B., Hannon, G., Feurdean, A., Ghergari, L., Onac, B.P., Posnnert, G. (2001), Reconstruction of climatic and environmental changes in NW Romania during the early part of the last deglaciation (15,000-13,600 cal years BP). Quaternary Science Reviews (in press).

Woldstedt, P. (1958), Das Eiszeitalter, 2. Ferdinand Enke Verlag, Stuttgart, pp. 438. 